\title{
Effect of organic manures on growth and yield attributes of Soybean (Glycine max L.) under Subabul (Leucaena leucocephala) based Agroforestry system
}

\author{
N. Khare, D. Kumar and S. Rout* \\ 211007 (Uttar Pradesh) INDIA \\ ${ }^{*}$ Corresponding author. E-mail: srout.forestry@gmail.com \\ Received: March 30, 2016; Revised received: September 19, 2016 Accepted: November 28, 2016
}

School of Forestry \& Environment, Sam Higginbottom Institute of Agriculture Technology \& Sciences, Allahabad-

\begin{abstract}
A field trail was carried out at the research farm of the School of Forestry and Environment, SHIATS, Allahabad. The experimental research site is situated at an altitude of $90 \mathrm{~m}$ above the sea level at $25.57^{0} \mathrm{~N}$ latitude and $81.51^{\circ} \mathrm{E}$ longitudes. The experiment comprised seven treatments replicated thrice. The maximum germination $\%$ (96.67\%), plant height $(83.73 \mathrm{~cm})$, number of branches/ plant (11.93), fresh weight $(185.28 \mathrm{~g})$, dry weight $(45.73 \mathrm{~g})$, at 110 days after sowing (DAS), number of pods/plant (91.67), number of seeds/pod (3.93), pod length (6.93 $\mathrm{cm})$, test weight $(90.73 \mathrm{~g})$, seed yield $(23.87 \mathrm{q} / \mathrm{ha})$, straw yield $(40.73 \mathrm{q} / \mathrm{ha})$ and harvest index $(36.94 \%)$ recorded in treatment $\mathrm{T}_{5}$. The result showed that the applications of organic manure (50\% Farmyard Manure $+50 \%$ Vermicompost) maximized the soybean growth and yield under subabul trees. Therefore, it may be concluded that $50 \%$ Farmyard Manure $+50 \%$ Vermicompost can be recommended for growing soybean under subabul based Agroforestry system for obtaining better growth and yield.
\end{abstract}

Keywords: Agroforestry, Organic manure, Soybean, Subabul, Vermicompost

\section{INTRODUCTION}

Agro forestry is primarily a system where agriculture and forestry are practices either simultaneously or separately on the same unit of land. Trees are grown in agricultural fields for many uses such as shade, fodder, fuel wood, fruits and small timbers. Apparently, the man has been practicing agro forestry since he learnt the art of cultivating agricultural crops and domesticating of livestock's and has never stopped using trees (Bene et al., 1977). Agro forestry system is not new in fact they are very old as tradition. The only new at present is the use of the term "Agro forestry". Agro forestry provides a different land use option, compared with traditional arable and forestry system. It makes use of the complimentary relationship between and crops, so that the availability of resources can be effectively utilized. It is a practice that supports the environment and has an obvious landscape benefit. Efficient, modern versions of Agro forestry have been developed, that are adapted to the constraints imposed by mechanization. The Agro forestry plot remains productive for the farmer and generates continuous revenue, which is not feasible in arable land. Agro forestry allows for the diversification of farm activities and makes better use of an environmental resource (Kumar, 2006). The potential benefit of growing trees in combination with annual and perennial crops is to maintain the productivity and fertility. Trees can also provide a number of other benefits, including soil improvement, erosion control, shade, windbreak, groundwater management, erosion control, habitat for wildlife, and perhaps, selenium harvesting. Subabul (Leucaena leucocephala) belongs to the family Fabaceae and sub-family Mimosaceae, it is also known as 'miracle tree' due to its paramount economic importance. Its common name is Ipil-ipil (Philippines). It is a fast growing thorn less, evergreen leguminous woody perennial. It is capable of growing in diversified agro-climate conditions of the tropical region. It also fixes atmospheric nitrogen equivalent to one tonne of ammonium sulphate per hectare/year assuming 1000 trees per hectare. The soil nutrient i.e. carbon, nitrogen, phosphorus and potassium content under tree plantation are higher as compared to open condition (Singh et al., 2007). Soybean (G. max L.) is a member of family Papilionaceae and believed to have originated in north-eastern china and distributed in Asia, USA, Brazil, Argentina etc. This crop is aptly called as "golden bean" or "miracle crop" of the $20^{\text {th }}$ century, because of its multiple uses. It has highest protein (42\%), 20 per cent oil rich in lycine and vitamins a, b and $\mathrm{d}$. Soybean occupies a premier position among crops, being the most important source of both protein concentrates and vegetable oil. As a legume it is capable of utilizing atmospheric nitrogen through biological nitrogen fixation and is therefore much less dependent on synthetic nitrogenous fertilizers than most 
non-legume crops. In addition, since the introduction of soybean into crop rotations often break the building up of pests and diseases in cereals. Soybean occupies 912.99 lakh ha of the area with 2099 million tonnes of annual production and $22.99 \mathrm{q}$ per ha productivity in the world. In India, it occupies 10.3 million ha of the area with 66 million tonnes of production and $9.56 \mathrm{q} /$ ha productivity (Mundewadikar and Deshmukh, 2014). Madhya Pradesh, Rajasthan, Karnataka, Uttar Pradesh, Andhra Pradesh are important soybean growing states of India in Karnataka, it is cultivated in an area of 1.418 lakh ha with a production of 1.149 million tonnes and production of $8.1 \mathrm{q} /$ ha. The soybean plant is classed as an oil seed rather than a pulse by the Food and Agricultural Organization (FAO, 2008). The successful cultivation of soybean under agro forestry required information assessment of the system. The information on these aspects of subabul based agro forestry system involving organic manures is meager. Keeping in view of the importance of the crops, a preliminary investigation was made to study the effect of different organic manures on growth and yield of soybean under subabul based Agro forestry System.

\section{MATERIALS AND METHODS}

The investigation was carried out at the research farm of School of Forestry and Environment, Sam Higginbottom Institute of Agriculture Technology and Sciences, Allahabad during the period of Kharif 2012. Evaluation of the compatibleness of Soybean (varieties - SL-688) with subabul based agro forestry system was carried out. Allahabad is situated at an elevation of 90 meters above the sea level; it is situated at $25.57^{0} \mathrm{~N}$ latitude and $81.51^{\circ} \mathrm{E}$ longitude. Allahabad is located in the South eastern part of Uttar Pradesh and has a subtropical climate with extremes of summer and winter. During the summer season, the temperature reaches up to $45-48^{\circ} \mathrm{C}$, while during the winter season, especially in the month of December and January temperature drops down to as low as $1-20^{\circ} \mathrm{C}$, frost and during summer, hot scorching wind are common features. The average rainfall in this area is around $886.00 \mathrm{~mm}$, during the monsoon i.e. July to September, with a few occasional light showers and drizzles are seen in the winter also (Maurya et al., 2016). Prior to starting the experiment the selected plot remained fallow in Rabi season, organic manures were used for the experiment. The organic manures used were well decomposed Farm Yard Manures, Vermicompost, and Neem Cake as per the following treatment details $\mathrm{T}_{0^{-}}$Control, $\mathrm{T}_{1^{-}}$ Farmyard Manure, $\mathrm{T}_{2}$-Vermicompost, $\mathrm{T}_{3}$ - Neem Cake, $\mathrm{T}_{4-}-50 \%$ Farmyard Manure $+50 \%$ Neem Cake, $\mathrm{T}_{5}-50 \%$ Farmyard Manure $+50 \%$ Vermicompost, $\mathrm{T}_{6}-50 \%$ Neem Cake $+50 \%$ Vermicompost. Pre sowing operation like ploughing, weeding and leveling, demarcation and layout application of organic fertilizer, sowing of seeds were carried out manually. After the sowing, timely irrigation and weeding of the field were carried out as and when required. First irrigation was done immediately after sowing of the crop while the subsequent irrigations were provided at 20 and 40 Days after sowing (DAS). Two manual weeding were provided at 15 and 40 DAS. Various post- sowing operation, i.e. inter culture operations were carried out as and when required as per the crop. The experiment was conducted in Randomized Block Design (RBD) having seven treatment combinations which were replicated thrice. Harvesting was carried during morning hour after 120 days of sowing. Visually yellowing of leaves indicates the maturity stage reached. Pre-harvest observations i.e., (at 30, 60, 90 and 110 DAS) - germination \%, plant height $(\mathrm{cm})$, number of branches plant, fresh weight (g), dry weight $(\mathrm{g})$ and post-harvest observation i.e., number of pods/ plant, number of seeds/pod, pod length $(\mathrm{cm})$, test weight $(\mathrm{g})$, seed yield $(\mathrm{q} / \mathrm{ha})$, straw yield $(\mathrm{q} / \mathrm{ha})$ were recorded and Harvest index $(\%)$ calculated. The raw data obtained during the experimental observations were subjected to statistical analysis as per method by Gomez and Gomez (1984). The significance and non-significance of the treatment effects were judged with the help of ' $F$ ' variance ratio test. Calculated ' $F$ ' value (variance ratio) was compared with the table value of ' $F$ ' at $5 \%$ level of significance.

\section{RESULTS AND DISCUSSION}

During the present course of investigation, it was revealed that the highest germination percentage was significantly affected by different treatments. The maximum germination was found in $\mathrm{T}_{5}(96.67 \%)$ and minimum germination was observed in $\mathrm{T}_{0}(78.33 \%)$, similar finding of higher germination percentage (96.76\%) also reported in case of Soybean (Mahesh babu et al., 2008). In case of plant height at 30 DAS, It was observed that plant height was non- significant by different treatments. The maximum plant height was found at $\mathrm{T}_{5}(28.53 \mathrm{~cm})$ and minimum plant height was observed in $\mathrm{T}_{0}(24.07 \mathrm{~cm})$, at 60 DAS it was observed that plant height was significantly affected by different treatments (Table 1). The maximum plant height was found in $\mathrm{T}_{5}(65.20 \mathrm{~cm})$ and minimum plant height was observed in $\mathrm{T}_{0}(49.27 \mathrm{~cm})$. At 90 DAS, It was observed that maximum plant height was found in $T_{5}$ $(83.00 \mathrm{~cm})$ and minimum plant height was observed in $\mathrm{T}_{0}(77.93 \mathrm{~cm})$. At $110 \mathrm{DAS}$, maximum plant height was found in $T_{5}(83.73 \mathrm{~cm})$ and minimum plant height was observed in $\mathrm{T}_{0}(79.27 \mathrm{~cm})$ under subabul based agroforestry system. Similar results in the case of plant height significantly highest $(66.86 \mathrm{~cm})$ were also reported by Kumar et al. (2015), in Linseed in teak based agro forestry system. Prakash et al. (2002) also reported that organic manures like FYM increase the plant height of C. officinalis, as compared to control. These results are in conformity with the findings of Yadav et al. (2000) where they reported that media consisting 
Table 1. Effect of organic manures on germination (\%) and plant height of Soybean (G. max L.) under Subabul (L. leucocephala) based agroforestry system.

\begin{tabular}{|c|c|c|c|c|c|c|}
\hline \multirow{2}{*}{ S. N. } & \multirow{2}{*}{ Treatments } & \multirow{2}{*}{$\begin{array}{c}\text { Germination } \\
(\%)\end{array}$} & \multicolumn{4}{|c|}{ Plant height (cm) } \\
\hline & & & 30 DAS & 60 DAS & 90 DAS & $110 \mathrm{DAS}$ \\
\hline $\mathrm{T}_{0}$ & Control & 78.33 & 24.07 & 49.27 & 77.93 & 79.27 \\
\hline $\mathrm{T}_{1}$ & $\begin{array}{l}\text { Farmyard Manure } \\
(\mathrm{FYM})\end{array}$ & 85.00 & 26.60 & 54.40 & 81.20 & 82.47 \\
\hline $\mathrm{T}_{2}$ & Vermicompost (VC) & 88.33 & 26.67 & 55.67 & 81.40 & 82.60 \\
\hline $\mathrm{T}_{3}$ & Neem Cake (NC) & 81.67 & 24.93 & 51.40 & 79.07 & 80.33 \\
\hline $\mathrm{T}_{4}$ & $\begin{array}{l}50 \% \text { Farmyard Manure }+ \\
50 \% \text { Neem Cake }\end{array}$ & 91.67 & 27.27 & 56.00 & 81.67 & 82.67 \\
\hline $\mathrm{T}_{5}$ & $\begin{array}{l}50 \% \text { Farmyard Manure + } \\
50 \% \text { Vermicompost }\end{array}$ & 96.67 & 28.53 & 65.20 & 83.00 & 83.73 \\
\hline \multirow[t]{2}{*}{$\mathrm{T}_{6}$} & $\begin{array}{l}50 \% \text { Neem Cake }+50 \% \\
\text { Vermicompost }\end{array}$ & 95.00 & 27.67 & 59.27 & 82.07 & 82.93 \\
\hline & C. D. $(P=0.05)$ & 3.17 & - & 2.08 & 0.27 & 0.177 \\
\hline
\end{tabular}

Table 2. Effect of organic manures on number of branches/plant of Soybean (G. max L.) under Subabul (L. leucocephala) based agroforestry system at different intervals.

\begin{tabular}{llllll}
\hline \multirow{2}{*}{ S. N. } & Treatment & \multicolumn{4}{c}{ Number of branches per plant } \\
\cline { 3 - 6 } & & \multirow{2}{*}{$\mathbf{3 0}$ DAS } & \multirow{2}{*}{ 60 DAS } & 90 DAS & 110 DAS \\
\hline $\mathrm{T}_{0}$ & Control & 3.93 & 8.20 & 10.87 & 11.40 \\
$\mathrm{~T}_{1}$ & Farmyard Manure (FYM) & 4.13 & 8.67 & 11.07 & 11.53 \\
$\mathrm{~T}_{2}$ & Vermicompost (VC) & 4.20 & 9.00 & 11.20 & 11.60 \\
$\mathrm{~T}_{3}$ & Neem Cake (NC) & 4.00 & 8.73 & 10.93 & 11.47 \\
$\mathrm{~T}_{4}$ & 50\% Farmyard Manure + 50\% Neem Cake & 4.27 & 9.53 & 11.33 & 11.67 \\
$\mathrm{~T}_{5}$ & 50\% Farmyard Manure + 50\% Vermicompost & 4.47 & 10.73 & 11.73 & 11.93 \\
$\mathrm{~T}_{6}$ & 50\% Neem Cake + 50\% Vermicompost & 4.33 & 10.33 & 11.47 & 11.73 \\
& C. D. (P = 0.05) & - & 0.40 & 0.12 & 0.13 \\
\hline
\end{tabular}

Table 3. Effect of organic manures on fresh weight of plant $(\mathrm{g})$ of Soybean (G. max L.) under Subabul (L. leucocephala) based agroforestry system at different intervals.

\begin{tabular}{|c|c|c|c|c|c|}
\hline \multirow{2}{*}{\multicolumn{2}{|c|}{ Treatments }} & \multicolumn{4}{|c|}{ Fresh weight of plant (g) } \\
\hline & & \multirow{2}{*}{$\begin{array}{l}\text { 30 DAS } \\
23.80\end{array}$} & \multirow{2}{*}{$\begin{array}{l}\text { 60 DAS } \\
52.73\end{array}$} & \multirow{2}{*}{$\begin{array}{l}90 \text { DAS } \\
92.93\end{array}$} & \multirow{2}{*}{$\frac{110 \text { DAS }}{122.20}$} \\
\hline $\mathrm{T}_{0}$ & Control & & & & \\
\hline $\mathrm{T}_{1}$ & Farmyard Manure (FYM) & 27.87 & 68.07 & 107.73 & 143.73 \\
\hline $\mathrm{T}_{2}$ & Vermicompost (VC) & 28.80 & 73.80 & 117.73 & 152.00 \\
\hline $\mathrm{T}_{3}$ & Neem Cake (NC) & 25.00 & 58.53 & 97.87 & 131.67 \\
\hline $\mathrm{T}_{4}$ & $50 \%$ Farmyard Manure $+50 \%$ Neem Cake & 30.07 & 79.60 & 123.87 & 162.13 \\
\hline $\mathrm{T}_{5}$ & $50 \%$ Farmyard Manure $+50 \%$ Vermicompost & 33.07 & 102.07 & 146.87 & 185.28 \\
\hline $\mathrm{T}_{6}$ & $50 \%$ Neem Cake $+50 \%$ Vermicompost & 31.27 & 89.13 & 135.33 & 174.67 \\
\hline & C.D. $(\mathrm{P}=0.05)$ & - & 5.78 & 6.02 & 9.29 \\
\hline
\end{tabular}

Table 4. Effect of organic manures on dry weight of plant (g) of Soybean (G. max L.) under Subabul (L. leucocephala) based agroforestry system at different intervals.

\begin{tabular}{llcccc}
\hline & \multirow{2}{*}{ Treatments } & \multicolumn{3}{c}{ Dry weight of plant (g) } \\
\cline { 2 - 5 } & Control & 30 DAS & 60 DAS & 90 DAS & 110 DAS \\
\hline $\mathrm{T}_{0}$ & Farmyard Manure (FYM) & 6.93 & 14.27 & 24.07 & 28.07 \\
$\mathrm{~T}_{1}$ & Vermicompost (VC) & 7.87 & 18.13 & 29.87 & 32.33 \\
$\mathrm{~T}_{2}$ & 8.20 & 19.53 & 33.40 & 34.80 \\
$\mathrm{~T}_{3}$ & Neem Cake (NC) & 7.27 & 16.20 & 26.80 & 29.93 \\
$\mathrm{~T}_{4}$ & 50\% Farmyard Manure + 50\% Neem Cake & 8.40 & 20.13 & 35.07 & 35.07 \\
$\mathrm{~T}_{5}$ & 50\% Farmyard Manure + 50\% Vermicompost & 8.87 & 26.73 & 39.53 & 45.73 \\
$\mathrm{~T} 6$ & 50\% Neem Cake + 50\% Vermicompost & 8.53 & 22.67 & 37.07 & 41.87 \\
& C. D. (P = 0.05) & - & 1.36 & 1.86 & 2.14 \\
\hline
\end{tabular}

red soil + FYM (1:1) was to be best in respect of plant height for marigold. At 30 DAS, It was observed that number of branches per plant was non - significant in different treatments. The maximum number of branches per plant was found in $\mathrm{T}_{5}(4.47)$ and minimum number of branches per plant was observed in $\mathrm{T}_{0}$ (3.93). At 


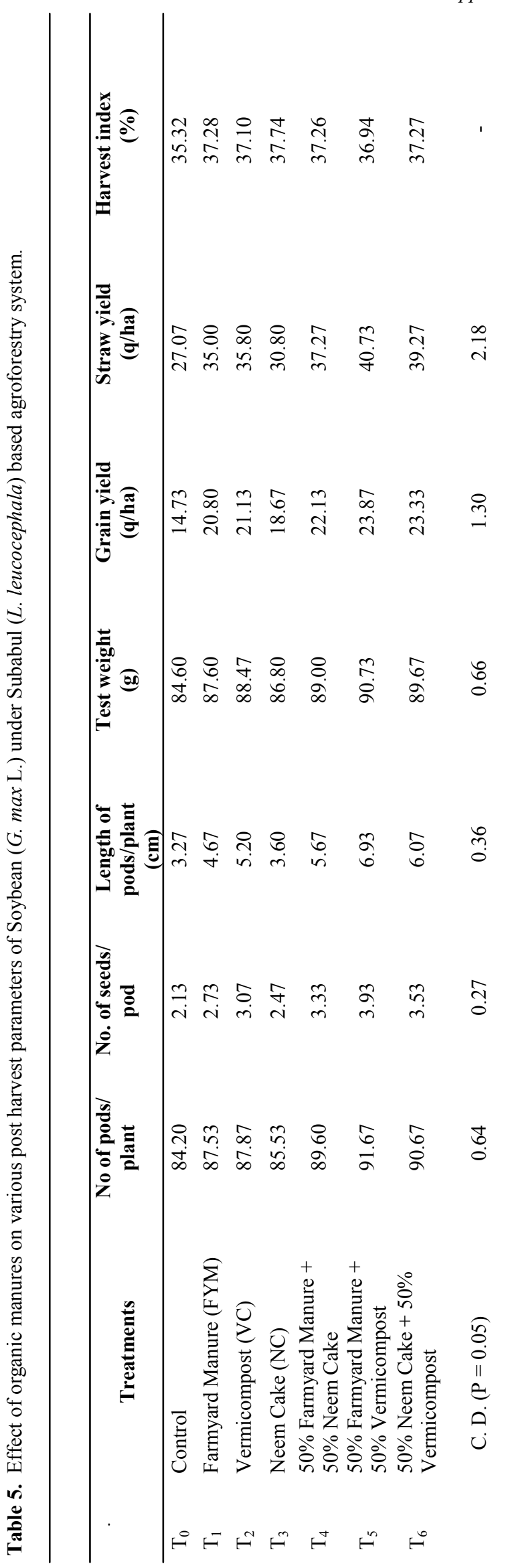

60 DAS maximum number of branches per plant was found in $\mathrm{T}_{5}(10.73)$ and minimum number of branches per plant was observed in $T_{0}$ (8.20) (Table 2). At 90 DAS maximum number of branches per plant was found in $\mathrm{T}_{5}(11.73)$ and minimum number of branches per plant was observed in $\mathrm{T}_{0}(10.87)$.At 110 DAS the maximum number of branches per plant was found in $\mathrm{T}_{5}$ (11.93) and minimum number of branches per plant was observed in $\mathrm{T}_{0}$ (11.40). The maximum fresh weight of plant was found in $\mathrm{T}_{5}(33.07 \mathrm{~g})$ and minimum fresh weight of plant was observed found in $T_{0}$ $(23.80 \mathrm{~g})$ at $30 \mathrm{DAS}$. In case at $60 \mathrm{DAS}$ maximum fresh weight of plant was found in $\mathrm{T}_{5}(102.07 \mathrm{~g})$ and minimum fresh weight of plant was observed found in $\mathrm{T}_{0}$ (52.73g). At 90 DAS maximum fresh weight of plant was found in $\mathrm{T}_{5}(146.87 \mathrm{~g})$ and minimum fresh weight of plant was observed found in $\mathrm{T}_{0}(92.93 \mathrm{~g})$. At 110 DAS maximum fresh weight of plant was found in $T_{5}$ (185.28g) and minimum fresh weight of plant was observed in $\mathrm{T}_{0}(122.20 \mathrm{~g})$ (Table 3$)$. This indicates that crop grown with incorporation or organic manures are benefited from it. It's not only as a source of nutrients but also provide good overall growth of crop (Arriage and Lowery, 2003) and crop yield (Nyiraneza and Snapp, 2007). At 30 DAS maximum dry weight of plant was found in $\mathrm{T}_{5}(8.87 \mathrm{~g})$ and minimum dry weight of plant was observed in $\mathrm{T}_{0}(6.93 \mathrm{~g})$ (Table 4).At 60 DAS maximum dry weight of plant was found in $T_{5}$ $(26.73 \mathrm{~g})$ and minimum dry weight of plant was observed in T0 $(14.27 \mathrm{~g})$. At 90 DAS maximum dry weight of plant was found in $\mathrm{T}_{5}(39.53 \mathrm{~g})$ and minimum dry weight of plant was observed in $\mathrm{T}_{0}(24.07 \mathrm{~g})$. At 110 DAS maximum dry weight of plant was found in $\mathrm{T}_{5}(45.73 \mathrm{~g})$ and minimum dry weight of plant was observed in $\mathrm{T}_{0}(28.07 \mathrm{~g})$ Maximum dry weight was recorded in $\mathrm{T}_{5}$ this may be due to the effect of different nutrient management practice which made significant variations at different stages of crop till harvest these findings are corroborated with the findings of Gayen et al. (2004). Maximum number of pod/plants (91.67) was recorded in the treatment $\mathrm{T}_{5}$ while the minimum number of pod/plants (84.20) was recorded in the treatment $\mathrm{T}_{0}$. Maximum number of seeds per pod (3.93) was recorded in the treatment $T_{5}$ while the minimum number of seeds per pod (2.13) was recorded in the treatment $\mathrm{T}_{0}$. Maximum pod length $(6.93 \mathrm{~cm})$ was recorded in the treatment $\mathrm{T}_{5}$ while the minimum pod length $(3.27 \mathrm{~cm})$ was recorded in the treatment $T_{0}$. Maximum grain yield $(23.87 \mathrm{q} / \mathrm{ha})$ was recorded in the treatment $T_{5}$, minimum grain yield $(14.73 \mathrm{q} / \mathrm{ha})$ was recorded in the treatment $\mathrm{T}_{0}$ (Table 5). Maximum straw yield $(40.73 \mathrm{q} / \mathrm{ha})$ was recorded in the treatment, minimum straw yield $(27.07 \mathrm{q} / \mathrm{ha})$ was recorded in the treatment $\mathrm{T}_{0}$. The highest harvest index (\%) was nonsignificantly affected at different treatments. The maximum harvest index (\%) was found in $\mathrm{T}_{3}(37.74 \%)$ and minimum harvest index was observed found in $T_{0}$ 
$(35.32 \%)$. The yield attributes are mainly depends on the crop growth and significantly affected by tree species, fertility levels as they affect soyabean growth. Similar results were reported by Kaushik and Singh (2001) in the case of Wheat. Apart from nutrient light is a major limiting factor for the crop growth and yield under tree species Corroborative results were also reported by Tripathi et al. (2001).

\section{Conclusion}

The different growth and yield parameters of soybean viz. maximum germination \% (96.67\%), plant height $(83.73 \mathrm{~cm})$, number of branches/ plant $(11.93)$, fresh weight $(185.28 \mathrm{~g})$, dry weight $(45.73 \mathrm{~g})$, at 110 days after sowing, number of pods/plant (91.67), number of seeds/pod (3.93), pod length $(6.93 \mathrm{~cm})$, test weight (90.73g), seed yield (23.87q/ha), straw yield (40.73 q/ ha) and harvest index (36.94\%) were recorded in treatment $\mathrm{T}_{5}(50 \%$ Farmyard Manure $+50 \%$ Vermicompost) under subabul based agro forestry system. So it may conclude that 50\% Farmyard Manure $+50 \%$ Vermicompost can be recommended to the grower for the cultivation of soybean under subabul based agro forestry system during the kharif season in Allahabad condition.

\section{REFERENCES}

Arriaga, J.F. and Lowery, B. (2003). Soil physical properties and crop productivity of an eroded soil amended with cattle manures. J. of Soil Sci., 168: 888-899

Bene, J.G., Beall, H.W. and Cote, A. (1977). Trees, food and people, IDRC, Ottawa, Canada

FAO (2008). State of food and agriculture. Rome, Italy: Food and Agriculture Organization in Developing Countries

Gayen, S.K., Gupta, D.K. and Sarawgi, S.K. (2004). Effect of decomposed cow dung and urine mixture with or without inorganic fertilizer, soil conditioning and PSB on the root volume and nodules performance of soybean [Glycine $\max (\mathrm{L}$.$) Merrill]. Annals of Agricultural$ Research, 25(4): 541-545

Gomez, K.A. and Gomez, A.A. (1984). Statistical procedures for Agricultural Res. 2nd edn. John Wiley and Sons, New York, 680 pp
Kaushik, N. and Singh, J. (2001). Performance of pearl millet-wheat in popular based agri-silvicultural system in sandy soils of southern Haryana. Indian J. of Agro forestry, 31(1): 51-54

Kumar, B.M. (2006). Agro forestry: the new old paradigm for Asian food security. Journal of Tropical Agriculture, 44(1-2): 1-14

Kumar, H., Umarao, R. and Tripathi, M.K. (2015). Varietal performance of Linseed planted at different pacing under Teak based agro forestry system. J. Int. Acad. Res. Multidiscip, 2(8): 261-268

Mahesh babu, H.M., Hunje, N.K., Patil, B. and Baba lad, H. B. (2008). Effect of organic manures on plant growth, seed yield and quality of soybean. Karnataka J. Agric. Sci., 21(2): 219-221

Maurya, S.K., Nath, S., Patra, S.S. and Rout, S. (2016). Effect of different dates of sowing on growth and yield of pearl millet (Pennisetum glaucum L.) varieties under Allahabad condition. International Journal of Science and Nature, 7(1): 62-69

Mundewadikar, D.M. and Deshmukh, P.R. (2014). Genetic variability and diversity studies in soybean [Glycine $\max$ (L.) Merrill] using RAPD Marker. International Journal of Scientific and Research Publications, 4(9): 1 $-4$

Nyiraneza, J. and Snapp, S. (2007). Integrated management of organic and organic nitrogen and efficiency in potato system. Soil Sci. Soc. Am. J., 71: 1508-1515

Prakash, A., Sindhu, S.S., Sharma, S.K. and Prakash, A. (2002). Effect of phosphorus and FYM on yield parameters of marigold in chloride dominated saline soil. Haryana Journal of Horticulture Sciences, 31(3-4): 207 $-210$

Singh, S.R., Najar, G.R. and Singh, U. (2007). Productivity and nutrient uptake of soybean (Glycine max) as influenced by bio-inoculants and farmyard manure under rain fed conditions. Indian Journal of Agronomy, 52 (4): 325-329

Tripathi, M.K., Saini, B.C. and Chaturvedi, S. (2006). Growth and yield of intercropped wheat under Salix-Dalbergia agro forestry system. Annals of Bio. of Agric. and Tech., Pantnagar, Uttrakhand, India

Yadav, P.K., Singh, S. Dhindwal, A.S. and Yadav, M.K. (2000).Effect of N and FYM application on floral characters and yield of African marigold. Haryana Journal of Horticulture sciences, 29(1-2): 69-71 